\title{
DISCLAIMER
}

This document was prepared as an account of work sponsored by the United States Government. Neither the United States Government nor any agency thereof, nor The Regents of the University of California, nor any of their employees, makes any warranty, express or implied, or assumes any legal liability or responsibility for the accuracy, completeness, or usefulness of any information, apparatus, product, or process disclosed, or represents that its use would not infringe privately owned rights. Reference herein to any specific commercial product, process, or service by its trade name, trademark, manufacturer, or otherwise, does not necessarily constitute or imply its endorsement, recommendation, or favoring by the United States Government or any agency thereof, or The Regents of the University of California. The views and opinions of authors expressed herein do not necessarily state or reflect those of the United States Government or any agency thereof or The Regents of the University of California and shall not be used for advertising or product endorsement purposes.

Lawrence Berkeley Laboratory is an equal opportunity employer. 


\section{Lawrence Berkeley Laboratory FY 1993 Site Development Plan}

Lawrence Berkeley Laboratory University of California

Berkeley, California 94720

\section{MASTER} DISTRIBUTION OF THIS DOCUMENT IS UNLIMITED 


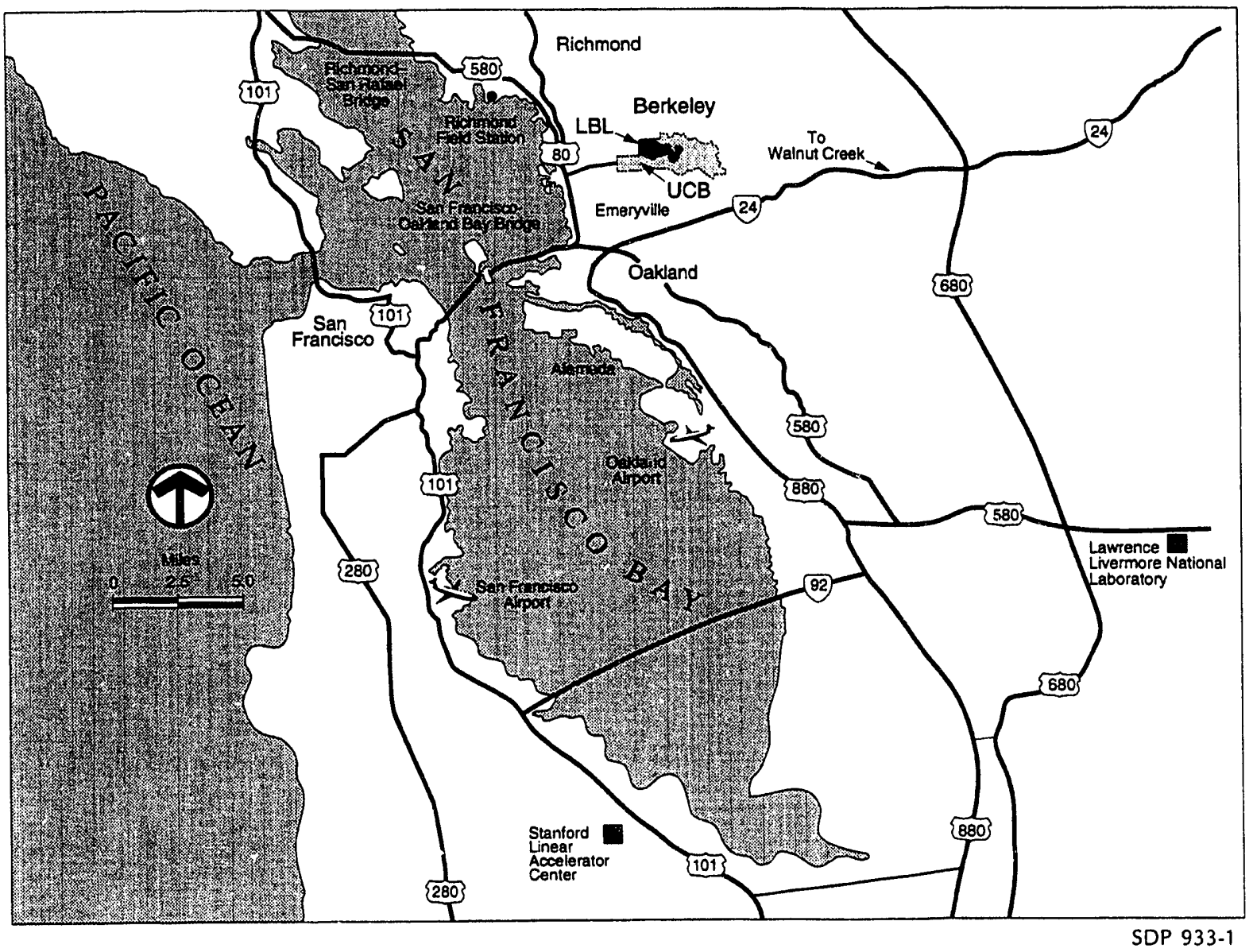

Lawrence Berkeley Laboratory, located in the hills overlooking the San Francisco Bay, is close to major highways and regional airports. 


\section{Preface}

The Lawrence Berkeley Laboratory (LBL) 1993 Site Development Plan (SDF) provides analysis and policy guidance for the effective use and orderly development of land and facilities at the LBL main site. The SDP directly supports LBL's role as a multiprogram national laboratory operated by the University of California (UC) for the Department of Energy (DOE). It is a concise policy document, prepared in compliance with DOE Order 4320.1B, and is coupled to the 1993 Laboratory Integrated Facilities Plan (LIFP). It also serves as the current DOE framework for the implementation of the 1987 Long Range Development Plan (LRDP) approved by the Regents of the University of California. The SDP is updated annually, with periodic major revisions consistent with DOE policy and approved plans of the Regents. The plan is reviewed and approved by the DOE San Francisco Field Office. The specific purposes of the SDP are to:

- Summarize the mission and community setting of the Laboratory;

- Describe program trends and projections and future resource requirements;

- Describe site planning goals and future facilities and land uses; and

- Describe site planning issues and potential infrastructure replacement solutions.

The SDP concisely expresses the policies for future development based on planning concepts, the anticipated needs of research programs, and site potential and constraints. The 1993 LIFP and other planning data provide detailed support for the plans identified in this document.

The SDP provides an essential framework for realizing the Laboratory vision, which is an outgrowth of LBL's strategic planning process. An essential element of that vision (which is stated entirely in the Institutional Plan and LIFP) is to:
Make $L B L$ the location of choice for facilities and programs. Our operational, administrative, and technical resources will integrate seamlessly with the research and engineering programs to make an $L B L$ that works. All of our activities will be conducted with full regard for the environment, health, and safety.

The SDP framework and infrastructure improvements proposed in this plan enable the realization of this aspect of LBL Vision 2000. These improvements provide for full regard of environment, safety, and health facilities needs and provide for efficient administrative and technical support facilities to make an LBL that works. They provide a national investment in research infrastructure for efficiency and cost effectiveness.

Preparation of the SDP was coordinated by the Office for Planning and Development with technical support of and data preparation by the Facilities Department. Programmatic data and information are from program divisions and technical resource divisions, including the Environment, Health \& Safety Division. The 1993 SDP is consistent with approved university guidelines and future building area, land use, and population projections identified in the 1987 LRDP and the 1987 Site Development Plan Environmental Impact Report and the 1992 Supplemental Environmental Impact Report prepared under the California Environmental Quality Act. 


\section{Director's Statement}

Proper site development is vital for the Lawrence Berkeley Laboratory to achieve its mission as a multiprogram energy research national laboratory. The Site Development Plan addresses the major issues and opportunities for site improvement that are critical to the continued fulfillment of this mission, under conditions that protect our staff, the public, and the environment. The Laboratory strongly supports this strategic planning activity as part of a national effort to restore and maintain the nation's scientific infrastructure. This planning activity is an integral part of the LBL strategic planning process, the objective of which is to realize LBL's Vision 2000 of a Laboratory that is the choice for national facilities and programs and that works effectively and efficiently.

Implementation of the Site Development Plan will require the continuing effort and support of the U.S. Department of Energy, the University, and the Laboratory community. 


\section{Table of Contents}

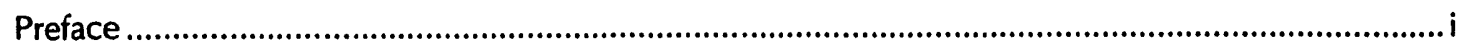

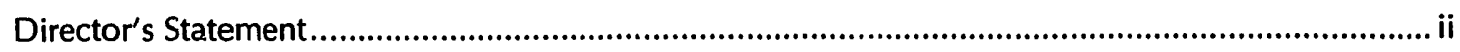

\section{Sections}

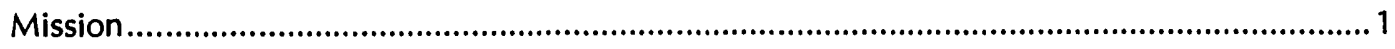

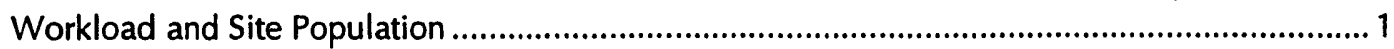

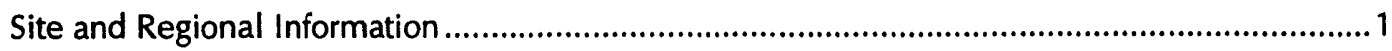

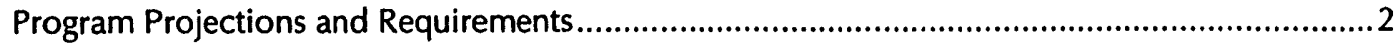

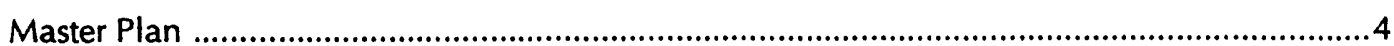

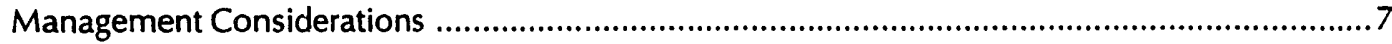

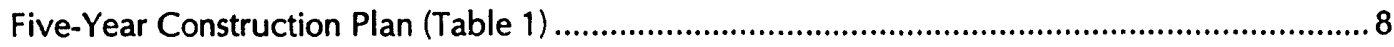

Appendix

Map 1. LBL Building Locations and Functional Areas .......................................................... A-3

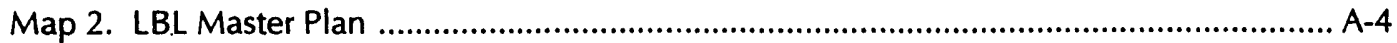

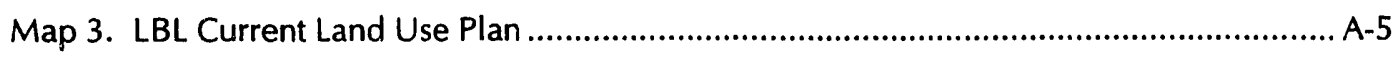

Map 4. Proposed Major Construction Projects (FY 1995-1999) ............................................ A-6 


\section{Mission}

The Laboratory, established in 1931 by Ernest $O$. Lawrence as a single-purpose acceleratorbased University research facility, has evolved into a multiprogram national laboratory with a mission to:

- Perform leading multidisciplinary research in the energy sciences, general sciences, and biosciences in a manner that ensures employee and public safety and the protection of the environment. The energy sciences include materials research, chemistry, earth science, and energy and environmental research. The general sciences include nuclear and highenergy physics and accelerator research. The biosciences include the life sciences and structural biology research.

- Develop and operate unique national experimental facilities for use by qualified investigators from throughout the world, including the Advanced Light Source, the 88Inch Cyclotron, the National Center for Electron Microscopy, and the National Tritium Labeling Facility.

- Educate and train future generations of scientists and engineers. 500 graduate students pursue research at $L B L$ with about 100 students receiving advanced degrees each year. Precollege programs are conducted for science educators and students.

- Foster productive relationships with industry. The Center for Advanced Materials, the Center for X-Ray Optics, and the California Institute for Energy Efficiency are examples of collaborations with industry. Technology transfer programs promote the application of research results.

\section{Workload and Site Population}

Program and Workload Areas. LBL programs are primarily supported by the DOE Office of Energy Research (62\%). The largest programs are in Basic Energy Sciences, Nuclear Physics, High Energy Physics, and Health and Environmental Research. Conservation and Renewable Energy (7\%) supports studies in building energy conservation, energy storage, and solar and geothermal energy. Other DOE-sponsored programs $(17 \%)$ include research on the Superconducting Super Collider, radioactive waste disposal, and fossil energy. Work for other agencies and institutions $(14 \%)$ is primarily for the National Institutes of Health, Department of Defense, state agencies, and private industry. Projected costs for FY 1993 are $\$ 261 \mathrm{M}$.

Laboratory Population. In 1993, the Laboratory's employee population consisted of 3,510 full- and part-time employees equating to 2600 full-time employees (see Fig. below).

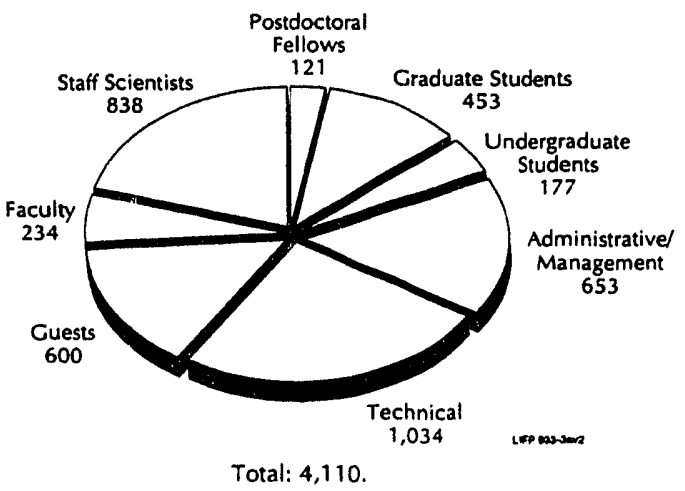

Laboratory Population in 1993.

LBL maintains a register of official guests, updated monthly, which contains 1,550 registered guests in 1993. About 600 of these guests were on site at any one time, so that total Laboratory population is 4,110 . Of this total, 3,480 are located at the main site, 500 located in UC Berkeley Campus buildings, and 130 located in off-site leased buildings. The 20-Year Plan would allow additional growth up to a total Laboratory average daily population of 4,750 , including 640 on the Campus.

\section{Site and Regional Information}

The 54-hectare (134-acre) Laboratory siti, located within 478 hectares (1180 acres) of University of California land, is leased by DOE through a series of 50-year lease agreements. The Laboratory is in Alameda County (population $1,280,000)$, with the eastern section in the City of Oakland $(370,000)$ and the western section in the City of Berkeley $(103,000)$. Although the area is largely urban and is served by interstate highways and an extensive. public transit system, the Laboratory site has hilly topography with areas of steep slopes and trees that give LBL a rural character. 
- Land Use and Topography. The Laboratory is on a hillside with elevations between 150 and 300 meters (500 to 1,000 feet). The site is zoned governmental and institutional by the cities of Berkeley and Oakland. On all sides of the Laboratory is a buffer zone of University land. In addition, the SDP provides for landscape buffer zones between LBL facilities and the Laboratory boundary and includes guidelines to ensure compatibility with land use outside the University buffer zone.

- Transportation Systems. The Laboratory and the cities of Oakland and Berkeley are served by a network of public transit systems, three major airports (San Francisco, Oakland, and San Jose), two railroads, and a network of interstate freeways and state highways. In addition, LBL operates shuttle buses around the site and between the Laboratory, the Campus, and the downtown Berkeley Bay Area Rapid Transit station.

- Public Utilities and Community Services. Electricity and natural gas are provided by the Pacific Gas and Electric Company, which anticipates adequate capacity for the foreseeable future. Water is supplied by the East Bay Municipal Utilities District. On-site storage and reservoirs adjacent to LBL provide water for anticipated emergency needs. The Utility District is currently expanding its supplies and storage capacity. The Laboratory provides its own fire protection service, which on occasion provides emergency assistance to the University and the City of Berkeley. Several hospitals are nearby.

- Condition of Buildings and Other Improvements. LBL research and support activities are conducted in structures totaling $180,000 \mathrm{gsm}$ (1.97 Mgsf) (ste Fig. above). In FY 1992 the average age of the main-site buildings was 33 years. The inventory of building space, including current construction, is: Adequate, $50,586 \mathrm{gsm}$ (544,500 gsf); Substandard, can be made Adequate, 82,479 gsm ( 887,800 gsf); and Substandard, cannot be made adequate, 20,132 gsm (216,700 gsf).

- Utilities. LBL's utilities distribution systems (mechanical, electrical, and communications) are underground. Many portions were initially sized to serve large accelerators and can meet present and future requirements. Aged

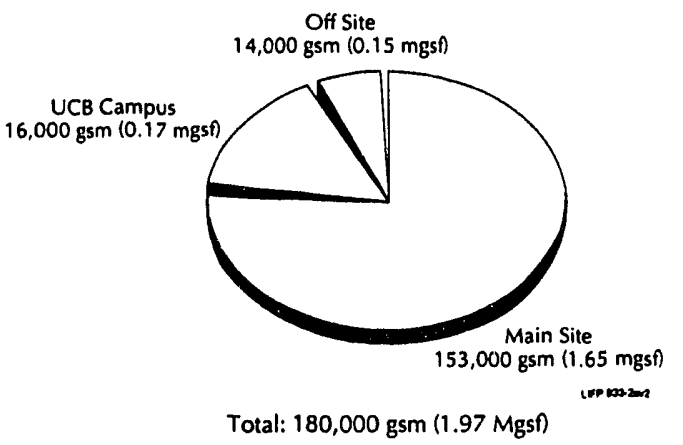

LBL 1992 Space Distribution.

segments require rehabilitation to improve flexibility and reliability. Utility systems undergoing rehabilitation include natural gas, domestic water, cooling water, electrical power, sanitary sewer, compressed air, storm drainage, standby and backup electricity, and alarm and security.

- Circulation and Traffic. LBL traffic circulates along an east-west central serpentine road, with north and south loops. Gates to the Laboratory are located at the ends of the central east-west road. These main roads were designed in the 1940s and early 1950s and no longer meet construction or safety standards. Neariy 7,000 vehicle trips per day are made to LBL, including 77 shuttle-bus trips off site and 102 on site. The off-site shuttle carries an average of about 2,300 passengers per day. Parking space is provided for 1,800 employee vehicles, with 1.8 employees per parking space.

\section{Program Projections and Requirements}

Mission Projections. LBL's research and support trends are assessed and described in the FY 1993-1998 Institutional Plan. The major changes in mission activity are in response to DOE's national programs in the Office of Basic Energy Sciences and the Office of Health and Environmental Research. In response to national needs for high-brightness synchrotron radiation facilities, LBL has completed construction of the Advanced Light Source. The Light Source provides the world's brightest beams of soft $x$-ray and ultraviolet light for use in materials science research, chemistry, biology, and other fields. When fully utilized with beamlines, the Light 
Source will provide ports for up to 55 end stations, including use by up to 200 guests at any one time. LBL must provide the research and facilities infrastructure to support this user community.

LBL has completed conceptual designs for a Human Genome Laboratory, the Induction Linac Systems Experiment, and, in coordination with other national laboratories, has prepared plans for a Chemica! Dynamics Research Laboratory for advanced studies in reaction science and combustion chemistry. Other projects include improvements to the National Center for Electron Microscopy and strengthened programs in the Center for Advanced Materials, and in the life sciences.

Specifics on the new program and support facilities required are given below in the functional areas of the Master Plan and the FiveYear Construction Plan.

Energy Sciences. The scientific outlook for the Energy Sciences is affected by developments in many scientific fields, but especially research in energy supply and efficiency technologies and in chemistry, geology, materials science, and physics. New program-related projects represent approximately $70 \%$ of LBL's anticipated increase in personnel or approximately $80 \%$ of the added LBL building area. The Laboratory views the following future research trends as important:

- Energy-use research important to national energy security will emphasize advanced high-efficiency combustion, energy storage, electric lighting, energy-intensive chemical processes, and energy flows through walls and windows. Reducing reliance on natural gas and other fossil fuels can mitigate emissions and waste disposal problems. Design of a new facility for support of building technologies is in process.

- Materials science research growth areas will support key materials of national interest, including materials with reduced dimensionality, high-temperature supercorıductors, semiconductors, composites, ceramics, light alloys, and polymers.

- New facilities for the staff of a molecular design program will be required. Chemistry of inorganic and complex organic molecules will require advanced facilities using intense photon beams, nuclear magnetic resonance spectroscopy, and laser spectroscopy.

- Earth sciences research will include geophysical investigations of the continental crust and physical and chemical studies of geological materials, including petroleum and geothermal reservoirs, and processes involving the transport and transformation of chemicals in complex geological structures. LBL requires staging areas, laboratories, and complete facilities to meet these needs.

General Sciences. LBL's general sciences programs are developed in conjunction with the high-energy and nuclear physics communities and with Federal programs in fusion research. New program-related projects represent approximately $20 \%$ of LBL's anticipated increase in personnel and no planned net increase in building area. LBL's general sciences programs include the following developments:

- Nuclear physics research will emphasize techniques that probe or alter the state of nuclei to explore nucleonic, hadronic, and quark-gluon matter. The Gammasphere at the LBL 88-Inch Cyclotron is central to continued research in nuclear structure. The STAR experiment collaboration is being planned at the Relativistic Heavy Ion Collider under construction at Brookhaven National Laboratory, and experimental facilities for studying unstable nuclei within an isospin laboratory are being considered. The Bevalac's nuclear physics operating program ended in February 1993, and a decommissioning plan is being developed.

- LBL will continue its high-energy physics research programs at the Tevatron and has a proposed B-Factory upgrade at the Positron-Electron Project at the Stanford Linear Accelerator. Further progress will become possible through the construction of the Superconducting Super Collider, including the Solenoidal Detector Collaboration led by LBL.

- LBL will continue its leading research in developing heavy-ion prototype accelerators for fusion in support of a technology that would ultimately employ accelerated beams of ions to ignite fusion fuel pellets. These research studies include the Induction Linac Systems Experiments. (The fuel pellet research will be conducted by other laboratories.) The 
development of neutral-beam testing facilities to evaluate supplemental plasma heating will continue in support of the magnetic-fusion program for the International Thermonuclear Experimental Reactor.

Biosciences. The support for human genome research is expected to grow, requiring an expansion of life-sciences-related facilities, and specifically the construction of a proposed Human Genome Laboratory. In addition, LBL supports DOE's structural biology initiative through the Laboratory's proposed instrumentation and mezzanine improvements at the Advanced Light Source (ALS), which will occupy existing buildings. New program-related projects represent approximately $10 \%$ of LBL's anticipated increase in personnel or approximately $20 \%$ of the added LBL building area. Programmatic growth areas are as follows:

- Physical mapping and eventual sequencing of the human genome will be emphasized, including human genome structure and expression, robotics, novel instrumentation, development of advanced computation techniques, and medical genetics.

- Structural biology research will be directed toward determining the relationship between the structure of biological macromolecules and their functions. The application of synchrotron radiation and advanced computational techniques will allow the determination of the three-dimensional structure of proteins and nucleic acids.

- Biomedical research will continue the application of advanced technology to study, diagnose, and treat human disease through innovations in positron emission tomography, NMR, and charged-particle radiation therapy and radiosurgery. A Biomedical Isotope Facility is under construction at an existing building to advance tomography research. A National Biomedical Tracer Facility, consisting of a $100-\mathrm{MeV}$ cyclotron and target areas, is also under consideration.

- Environmental and health-effects research will include atmospheric chemistry and transport, deposition, and ecological effects of combustion products. Studies of sources and transport of chemicals from the subsurface environment will cover contamination of groundwater, radon exposure, and other pollutants.

Laboratory Projected Resources and Workload. Laboratory operating costs are projected to increase from $\$ 212 \mathrm{M}$ in 1993 to $\$ 234 \mathrm{M}$ in 1998. Total Laboratory funding, including equipment and construction, is projected to increase from $\$ 261 \mathrm{M}$ in 1993 to $\$ 299 \mathrm{M}$ in 1998. Near-term workload increases are projected, based on the operating budgets of the ALS, human genome program, and initiatives associated with DOE's Division of Chemical Sciences.

Population Projections. The main-site population is projected to increase from 3,600 in FY 1993 to approximately 3,800 in FY 1998. The total projected Laboratory population will increase from 4,130 in FY 1993 to approximately 4,390 in FY 1998. The long-term projected growth at the site, identified in the 1993 LIFP, allows for an average daily main-site population of 4,100. The potential total Laboratory population (includes main site, Campus, and offsite areas) of 4,750 could be obtained within the 20-year master plan if national and regional programs require this growth.

\section{Master Plan}

Site planning at the Laboratory reflects longrange institutional goals and values based on the University's management of LBL to support DOE missions. The site development planning objectives are to:

- Evaluate future mission projections and anticipate DOE national research facility needs;

- Ensure a safe and healthful workplace in full compliance with building and fire codes;

- Protect the environment and buffer activities to enhance adjacent land uses;

- Protect the national investment in valuable government-owned research and support facilities;

- Consolidate research and support services through proper siting of new buildings;

- Improve access and communications within and to the Laboratory; and 
- Promote cost reductions and energy conservation through efficient design, location, maintenance, parking, and transportation.

Five LBL site master plan concepts accommodate the facilities improvement needs within existing geophysical, environmental, and operational conditions. They provide a basis for understanding and evaluating the more detailed elements of specific projects, planned locations, and other site improvement projections. The site planning concepts are to:

- Consolidate activities within seven functional planning areas to enhance efficiency and effectiveness and to provide specialized research facilities;

- Redevelop obsolete buildings and deteriorated infrastructure, eliminate temporary structures used for permanent functions, and improve building arrangements to increase safety and energy efficiency;

- Concentrate development along the east-west circulation and utilities axis to enhance transportation and service systems (e.g., offroad parking and improve pedestrian paths);

- Improve and maintain perimeter and internal buffer zones to screen noise-generating activities and minimize potential incompatibility between adjacent operations; and

- Provide off-site facilities for receiving, wareinousing, and other support and research activities suitable for decentralization.

Design guidelines for site development (see Table below) have been developed to achieve specific improvements while respecting site constraints and have provided coherence between buildings and their surroundings. These guidelines, described in more detail in LIFP, address the following areas: safety considerations; utilities corridors; building mass,

Site development guidelines.

\begin{tabular}{lcc}
\hline $\begin{array}{l}\text { Design } \\
\text { Guidelines }\end{array}$ & 1993 & 20-Year Plan \\
\hline Buildings & $\begin{array}{c}150,000 \mathrm{gsm} \\
(1.62 \mathrm{Mgsf})\end{array}$ & $\begin{array}{c}190,000 \mathrm{gsm} \\
(2.0 \mathrm{Mgsf})\end{array}$ \\
Undeveloped Land & $\begin{array}{c}32 \text { hectares } \\
(80 \text { acres })\end{array}$ & $\begin{array}{c}31 \text { hectares } \\
(78 \text { acres })\end{array}$ \\
$\begin{array}{l}\text { Improvements } \\
\text { (\% of total land area) }\end{array}$ & $38 \%$ & $42 \%$ \\
\hline
\end{tabular}

orientation, and exteriors; energy and operational efficiency; building use flexibility; circulation and parking; topography and grading; landscaping and open space; and guideline conformance review.

Facility and Land Requirements. If all the sites and buildings were developed in accordance with the 20-Year Plan, the result would be a net increase of approximately 40,000 gsm (0.4 Mgsf) to the existing main site of the Laboratory, for a total of approximately $190,000 \mathrm{gsm}$ (2.0 Mgsf). For comparison, the 1993 total, including current construction, consisted of 150,000 gsm (1.62 Mgsf) at the main site. The 20-Year Plan increases provide for growth in life sciences, chemistry and materials sciences, conservation and renewable energy, earth sciences, and fossilenergy research. The SDP calls for the removal of 20,000 gsm (0.2 Mgsf) of buildings and the renovation of $70,000 \mathrm{gsm}(0.8 \mathrm{Mgsf})$ of building space. Building sites are planned or reserved for $60,000 \mathrm{gsm}$ (0.6 Mgsf) of new construction. As indicated in the Planning Analysis section, increases are primarily for programmatic purposes. Proposed general-purpose facilities replace existing obsolete facilities.

Future Land Use. 32 hectares ( 80 acres) of the site are currently in undeveloped open space. Some of the open space is within buffer zones where development is limited for a variety of reasons. If all projects identified in the 20-Year Plan were completed, 31 hectares (78 acres) would be retained as open space and buffer. The proportion of the LBL main site that has been improved with structures, utilities, or roads would change from the current $38 \%$ to $42 \%$. Nine buffer zones are described in the LIFP, with specific planning criteria identified.

Future Major Facility Locations and Functional Areas. The functional planning areas are groupings of related facilities that enhance work efficiency and effectiveness. Building clusters form the core of each functional area, with circulation access, service, and parking at the perimeter. The 20-Year Plan identifies changes to each of the functional planning areas to accommodate potential research activities and to conform to LIFP objectives, planning concepts, and design guidelines.

The natural constraints of the site coupled with the desirability of maintaining efficient 
programmatic development delineate the seven functional planning areas:

- 88-inch Cyclotron Research Area, located on a hillside terrace near the Main Gate, currently includes buildings totaling $4,810 \mathrm{gsm}(51,800$ gsf). The area is expected to continue to be dedicated to the operation of the 88-inch Cyclotron and required support facilities. A second floor addition to support users of the Gammasphere and other experiments is under construction.

- Central Research and Administration Area houses the LBL Director's Offices and the main offices for Administration, Plsnning and Development, Accelerator and Fusion Research, Earth Sciences, Energy and Environment, Engineering, Information and Computing Sciences, Nuclear Science, and Physics. The majority of LBL's light laboratories arid support offices, as well as the cafeteria and visitor center, are included within these complexes, with a total of $45,140 \mathrm{gsm}$ $(485,900 \mathrm{gsf})$ in building space. Current plans call for marıy building projects, including additional floors for Buildings 50E and 50F, a new visitor center, additions to the cafeteria, and the development of a conference facility. Projects in slope stabilization and in seismic rehabilitation of Building 90 are in progress, which will free up space currently occupied by trailers for use as parking and circulation.

- Bevalac Accelerator Complex currently includes $33,270 \mathrm{gsm}(358,100 \mathrm{gsf})$ of building space. These facilities are located on three benches separated by steep slopes. Existing facilities include the Bevalac, heavy laboratory experimental areas, cryogenic support facilities, staging areas, associated offices, and facilities for advanced accelerator research and development. The proposed Master Plan anticipates the reuse of buildings for accelerator facilities and experiments, including the Induction Linac Systems Experiment. This area already has an extensive array of support utilities, crane and hoisting equipment, and related resources. Proposed new experiments could be located in the existing Experimental Hall, Building 51B, requiring little or no expansion of existing structures. Eventual decommissioning of the Bevatron and SuperHILAC accelerat s.s and shielding is expected.
- Light Source Research and Engineering Area encompasses approximately 6 hectares $(15$ acres), with buildings currently totaling 33,940 gsm $(397,600 \mathrm{gsf})$. Projects planned to útilize the ALS facility include the Instrumentation Project, the ALS structural biology facilities, the Chemical Dynamics Research Laboratory, and an ALS reception center. A special research facility zone has been established around the perimeter of the ALS to reserve areas for programs requiring the use of the ALS photon beams.

- Shops and Support Facilities Area includes $16,160 \mathrm{gsm}(174,000 \mathrm{gsf})$ of building space in an area adjacent to the Laboratory's Grizzly Gate entrance. Uses curre ttly include Craft, Construction, and Maintenance Shops; Supply Shops; Supply Services; Transportation and Motor Pool; Mechanical Shops; the Environment, Health and Safety Division; and the National Tritium Labeling Facility. The Hazardous Waste Handling Facility is being relocated from this area to the Life Sciences Research Area. Consolidation of support facilities will continue with the construction of the Safety and Support Services Facility and a proposed Facilities Building.

- Materials and Chemistry Research Area includes the Materials and Molecular Research Laboratory, the National Center for Electron Microscopy, and the Surface Science and Catalysis Laboratory. Current building area totals $11,500 \mathrm{gsm}(124,000 \mathrm{gsf})$. Plans include upgrades to the National Center for Electron Microscopy as well as a high bay addition to Building 62. All new development must take into account the visibility of this area from campus locations, including Strawberry Canyon below. The "Chicken Creek area" affords potential for additional facilities for research in cooperation with the UCB Campus.

- Life Sciences Research Area includes 4.4 hectares (11 acres) located in upper Strawberry Canyon in the easternmost portion of the LBL site also known as the East Canyon. Existing buildings include the Biomedical Laboratory, the Laboratory for Cell Biology, and the new Hazardous Waste Handling Facility (under construction) for a total $5,350 \mathrm{gsm}(57,600 \mathrm{gsf})$. Proposals for this area include the Human Genome Laboratory, expansion of the Life Sciences facilities, parking structures, and an 
office/bridge structure to provide safe pedestrian passage between builc'ings.

Utilities Systems. Many of the utilities systems were initially installed during the 15.40 s and require upgrades or replacement to achieve improved levels of reliability and service capacity. Many systems have adequate capacity but require extensions or improvements to achieve satisfactory performance and maintenance efficiency.

- Electrical Utilities. LBL's power-distribution system comprises a main 12-kV switching center at the Grizzly Utility Substation and 24 substations with $32 \mathrm{~km}$ of $12-\mathrm{kV}$ cable. A sixphase electrical system rehabilitation and improvement program will install six $12-k V$ switching stations throughout the Laboratory site and replace five aged and obsolete substations and all of the underground 12-kV distribution cable.

- Mechanical Utiiities. Mechanizal utilities comprise domestic and cooling water, storm drains and sanitary sewers and natural gas, compressed-air, and vacuum systems. These utilities are up to $\mathbf{4 0}$ years old, and many are undersized for current Laboratory demands. The 10-Year and 20-Year Plans provide for the orderly replacement of these utilities.

Utilities and fuel usage.

\begin{tabular}{ll}
\hline Utility system & FY 1992 usage \\
\hline Electricity & $81,000 \mathrm{MWh}$ \\
Natural gas & $12.07 \mathrm{~m}^{3}$ \\
& $(130$ million cu ft $)$ \\
Domestic water & 265 million L \\
& $(70$ million gallons $)$ \\
Vehicle gasoline & $326,670 \mathrm{~L}$ \\
& $(86,300$ gallons $)$ \\
Diesel fuel & $105,990 \mathrm{~L}$ \\
& $(28,000$ gallons $)$ \\
Liquified petroleum gas & $4,920 \mathrm{~L}$ \\
& $(1,300$ gallons $)$ \\
\hline
\end{tabular}

\section{Management Considerations}

LBL's site-planning management issues focus on replacing the deteriorated DOE research infrastructure buildings to achieve the Laboratory's mission safely and to protect the environment. These issues include restoring and rehabilitating obsolete buildings, consolidating support functions, improving the reliability of utility systems, ensuring a safe working environment, and accommodating the increasing numbers of scientific guests and visitors using LBL's national research facilities.

Many of LBL's site-development issues stem from obsolete, deteriorated facilities constructed during World War II and the immediate postwar period. During the past several years, DOE has begun significant investments to correct deficiencies in mechanical and electrical utility systems and programmatic facilities for materials research. A five-year construction plan for programmatic and general-purpose facilities is provided in Table 1, and major projects are identified in Map 4 (see Appendix).

The facilities issues being addressed by LBL and DOE during the five-year construction planning period include:

- Programmatic Facilities. Programmatic facilities primarily provide capability for the OER. These facilities projects include the Chernical Dynamics Research Laboratory $(3,066 \mathrm{gsm} ; 33,000 \mathrm{gsf})$ and the Human Genome Laboratory (3,809 gsm; 41,000 gsf). The completion of existing space and additions are proposed for the ALS instrumentation and user facilities $(2,601 \mathrm{gsm} ; 28,000 \mathrm{gsf})$. Other programmatic projects include modifications for heavy-ion accelerator research (e.g., Induction Linac Systems Experiment: 1,858 gsm; 20,000 gsf). Each programmatic facility, like general-purpose facilities, integrates the National Environmental Policy Act; the California Environmental Quality Act; and environment, safety, and health considerations into siting, design and project review from the early conceptual phases through completion of construction and operation. Planning is also under way for facilities that contribute to research infrastructure for an IsoSpin Laboratory, National Biomedical Tracer Facility, biomolecular design, and building technologies.

- Accelerator Improvement Projects. ALS will install new equipment systems for enhanced overall performance of the accelerator storage ring and beamline development. These 
Table 1

\section{LAWRENCE BERKELEY LABORATORY CONSTRUCTION PLAN}

\section{FY 1995-FY 1999}

Plan for Programmatic and General Purpose Facilities, Including Funded, Budgeted and Proposed Construction (FY BA, \$M)

\begin{tabular}{|c|c|c|c|c|c|c|c|c|c|c|}
\hline Project & Scope & TEC & Prior* & 1995 & 1996 & 1997 & 1998 & 1999 & 2000 & 2001 \\
\hline \multicolumn{11}{|l|}{ FUNDED PROGRAM RELATED PROJECTS: } \\
\hline Biomedical Isotope Facility & $186 \mathrm{gsm}(2,000 \mathrm{gsf})$ & 2.3 & 2.3 & & & & & & & \\
\hline SUBTOTAL - FUNDED PROGRAM RELATED & & 2.3 & 2.3 & & & & & & & \\
\hline \multicolumn{11}{|l|}{ FUNDED MEL-FS PROJECTS (KG): } \\
\hline $\begin{array}{l}\text { Envir Health \& Safety Proj (ER Program) } \\
\text { Building } 90 \text { Seismic Rehabilitation }\end{array}$ & $8,203 \mathrm{gsm}(88,300 \mathrm{gsf})$ & $\begin{array}{r}13.163 \\
6.800\end{array}$ & $\begin{array}{r}13.163 \\
6.800\end{array}$ & & & & & & & \\
\hline East Canyon Electrical Safety Project & & 3.900 & 2.900 & 1.000 & & & & & & \\
\hline Roof Replacements, Phase I & & 2.500 & 2.500 & & & & & & & \\
\hline Fire \& Safety Systems Upgrade Proj, Ph I & & 4.600 & 1.500 & 2.000 & 1.100 & & & & & \\
\hline Hazardous Materials Safeguards, Ph I & & 5.100 & 1.500 & 2.500 & 1.100 & & & & & \\
\hline SUBTOTAL - FUNDED MEL-FS PROJECTS & & 36.063 & 28.363 & 5.500 & 2.200 & & & & & \\
\hline \multicolumn{11}{|l|}{ FUNDED ERWM PROJECTS: } \\
\hline $\begin{array}{l}\text { Hazardous Waste Handling Facility } \\
\text { Envir Health \& Safety Proj (ERWM Program) }\end{array}$ & 1,198 gsm $(12,900 \mathrm{gsf})$ & $\begin{array}{r}12.0 \\
1.1\end{array}$ & $\begin{array}{r}12.0 \\
1.1\end{array}$ & & & & & & & \\
\hline SUBTOTAL - FUNDED ERWM PROJECTS & & 13.1 & 13.1 & & & & & & & \\
\hline TOTAL FUNDED & & 51.5 & 43.8 & 5.5 & 2.2 & & & & & \\
\hline \multicolumn{11}{|l|}{ BUDGETED MEL.FS PROJECTS (KG) } \\
\hline \multicolumn{11}{|l|}{ No new project starts in FY 1994} \\
\hline TOTAL FUNDED and BUDGETED & & 51.5 & 43.8 & 5.5 & 2.2 & & & & & \\
\hline \multicolumn{11}{|l|}{ PROPOSED PROGRAM RELATED PROJECTS: } \\
\hline Human Genome Laboratory (KP) & $3,809 \mathrm{gsm}(41,000 \mathrm{gsf})$ & 24.7 & 2.2 & 15.6 & 5.9 & 1.0 & & & & \\
\hline ALS Structural Biology Support Facilities & $1,031 \mathrm{gsm}(11,100 \mathrm{gst})$ & 7.9 & 0.6 & 4.7 & 2.6 & & & & & \\
\hline ALS Beamlines Initiative (KC) & 1,877 gsm (20,200 gsi) & 65.0 & & 15.0 & 20.0 & 15.0 & 10.0 & 5.0 & & \\
\hline Induction Linac Systems Experiment (AT) & $595 \mathrm{gsm}(6,400 \mathrm{gsf})$ & 61.0 & & 8.3 & 13.1 & 14.0 & 13.5 & 12.1 & & \\
\hline Chemical Dynamics Research Laboratory (KC) & $3,066 \mathrm{gsm}(33,000 \mathrm{gsf})$ & 55.9 & & 7.1 & 16.9 & 16.2 & 10.2 & 5.5 & & \\
\hline SUBTOTAL - PROPOSED PROGRAM RELATED & & 214.5 & 2.8 & 50.7 & 58.5 & 46.2 & 33.7 & 22.6 & & \\
\hline \multicolumn{11}{|l|}{ PROPOSED MEL-FS PROJECTS: } \\
\hline Safety \& Support Services Facility & $3,047 \mathrm{gsm}(32,800 \mathrm{gsf})$ & 12.3 & & 1.2 & 6.1 & 5.0 & & & & \\
\hline Upgrd of Site Mech Util, Ph II - Sewer Monit & & 8.8 & & 0.9 & 4.5 & 3.4 & & & & \\
\hline Envir Monitoring \& Industrial Hygiene Bldg & $2,973 \mathrm{gsm}(32,000 \mathrm{gsf})$ & 24.0 & & 2.5 & 17.0 & 4.5 & & & & \\
\hline Roadway Safety \& Stabilization, Phase I & & 6.8 & & & 0.9 & 4.5 & 1.4 & & & \\
\hline Sanitary Sewer Restoration, Phase I & $1,036 \mathrm{~m}(3,400 \mathrm{ft})$ & 2.7 & & & 0.3 & 1.8 & 0.6 & & & \\
\hline LBL Conduit Infrastructure Improvements & & 3.7 & & & 0.4 & 1.9 & 1.4 & & & \\
\hline Upgrade of LBL Communications System & & 4.5 & & & 0.5 & 2.2 & 1.8 & & & \\
\hline Facilities Building & $2,657 \mathrm{gsm}(28,600 \mathrm{gsf})$ & 15.9 & & & 1.6 & 9.0 & 5.3 & & & \\
\hline Medical Serv Asbestos Abatement \& Rehab & & 3.1 & & & & 0.3 & 2.0 & 0.8 & & \\
\hline Mechanical Equipment Replacement, Ph I & & 4.9 & & & & 0.5 & 2.5 & 1.9 & & \\
\hline Roof Replacements, Ph II & & 7.2 & & & & 0.7 & 3.6 & 2.9 & & \\
\hline Elec Sys Rehab, Ph IN - Blkby Swit Sta Replc & & 7.1 & & & & 0.7 & 3.5 & 2.9 & & \\
\hline Old Town Parking Structure & $3,252 \mathrm{gsm}(35,000 \mathrm{gsf})$ & 2.9 & & & & 0.3 & 1.5 & 1.1 & & \\
\hline Blackberry Canyon Parking Structure & & 22.2 & & & & & 2.2 & 11.0 & 9.0 & \\
\hline Admin Services Addn - Bldg 50E/F 2nd FI & $1,709 \mathrm{gsm}(18,430 \mathrm{gsf})$ & 9.1 & & & & & 0.9 & 4.5 & 3.7 & \\
\hline Fire \& Safety Systems Upgrd Project, Ph II & & 5.5 & & & & & 0.5 & 2.7 & 2.3 & \\
\hline Hazardous Materials Safeguards, Phase II & & 7.8 & & & & & 0.8 & 3.7 & 3.3 & \\
\hline Research Incubator Facility & & 17.2 & & & & & & 1.7 & 9.4 & 6.1 \\
\hline Technology Transfer Building & & 11.5 & & & & & & 1.2 & 7.0 & 3.3 \\
\hline Maintenance Bldg Replcmt, Ph I - Bldg 76 & $2,787 \mathrm{gsm}(30,000 \mathrm{gsfl})$ & 6.3 & & & & & & 0.6 & 3.0 & 2.7 \\
\hline Elec Sys Upgrd, Ph V - Cntrl Swit Sta \& Feedrs & & 6.6 & & & & & & 0.7 & 3.3 & 2.6 \\
\hline SUBTOTAL - PROPOSED MEL-FS PROJECTS & & 190.1 & & 4.6 & 31.3 & 34.8 & 28.0 & 35.7 & 41.0 & 14.7 \\
\hline TOTAL FUND, BUDGT \& PROP MEL-FS PROJ & & 226.2 & 28.4 & 10.1 & 33.5 & 34.8 & 28.0 & 35.7 & 41.0 & 14.7 \\
\hline
\end{tabular}

Table does not include unscheduled program-related projects.

February 1993 escalation rates at $3.3 \%, \mathrm{FY}^{\prime} 94 ; 3.6 \%, \mathrm{FY}^{\prime} 95 ; 3.7 \%$, $\mathrm{FY} ' 96 ; 3.7 \%, \mathrm{FY} \mathrm{F}^{\prime} 97 ; 3.6 \%$, FY'98.

- Prior costs from previous fiscal years. 
additions will enhance experimental equipment and beamline components, provide photon beam stabilization, and include accelerator system upgrades to improve performance. The installation of the electron cyclotron resonance source at the 88 -Inch Cyclotron has resulted in greater than fivefold increase in beam intensity. Design efforts for a next-generation source are under way.

- Environmental Restoration and Waste Management. LBL environmental management site projects and operating activities are essential to correct and restore environmental conditions and to improve the management of waste handling operations in support of DOE's national environmental objectives. Key facilities needs include completion of the hazardous waste handling facility and decommissioning the Bevalac accelerators.

- Safety and Health. The Laboratory has prepared a detailed Safety and Health FiveYear Plan. The prioritized plan strengthens DOE Safety and Health management and improves the allocation of Safety and Health resources. Key projects for health, safety, and environmental compliance are included and are necessary to implement the Corrective Action Plan. As part of its current comprehensive review, $L B L$ has requested $D O E$ support for a sitewide Environmental Assessment.

- Decommissioning Plan. LBL's Bevalac accelerators were shut down by February of 1993. Associated costs for preparation and decommissioning of the accelerators are being identified and reviewed by the Office of Energy Research and Environmental Restoration and Waste Management as detailed in LIFP.

- Multiprogram Energy Laboratory Facility Support (MEL-FS). The total proposed ten-year (FY 1995-FY 2004) MEL-FS program will require budget authority of $\$ 100 \mathrm{M}$ for this period. This modernization program addresses needs primarily related to the many buildings and utilities that are 20-40 years old and need improved safety, mechanical, electrical, and structural systems to meet current design standards. Full modernization of the main site requires a long-term 20-year investment program. Individual projects are evaluated against Laboratory SDP priorities: (1) safety systems and safety facilities, (2) environmental protection, (3) utilities reliability, (4) design standards and obsolescence, and (5) delivery of research and support services (see Fig. below).

- Building Replacement and Rehabilitation. During the near term, LBL's modernization plans call for construction to improve the safety and facility services infrastructure. The plan includes removal of obsolete, inefficient, and substandard facilities that cannot be made adequate and replacement of temporary structures for support activities.

- Safety Improvements. Safely and Health improvements began in FY 1988 and include fire protection upgrades; hazardous materials control upgrades; removal of asbestos; and improvements to safety services, medical services, buildiñ illumination, radiation protection, waterpollution control, and monitoring.

- Utilities. In the next five years, the LBL main-site electrical power system upgrade plan calls for the completion of the first three phases and work to begin on the fourth phase of a six-phase program that will result in the upgrade of the underground $12-\mathrm{kV}$ power distribution system and the installation of six new cirsuit breaker switching stations throughout the site. Mechanical utilities comprise domestic and cooling water, storm drains and sanitary sewers, natural

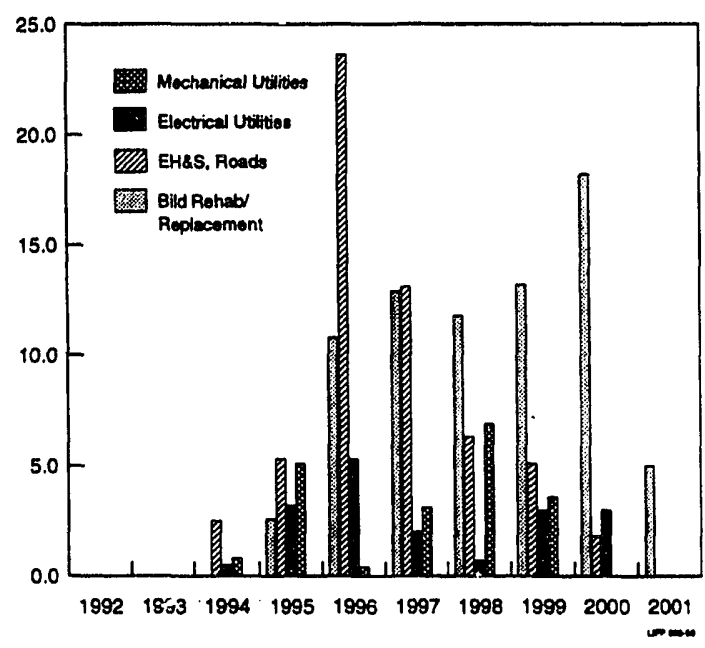

Ten-year Multiprogram Energy Laboratory Facility Support Backlog. 
gas, compressed-air, and vacuum systems. The modernization plans provide for the orderly replacement of these utilities and will help prevent potential damage to the environment. Scheduled utilities improvements only correct existing deficiencies; any delays will engender further deterioration of these essential utilities.

- General Plant Projects (GPP). Funding to date has been inadequate to meet the Laboratory needs within a timely schedule. This program has a significant backlog of projects, exceeding $\$ 30 \mathrm{M}$. Roughly a third of this backlog is for environment, health, and safety needs; a third is for utilities safety and reliability, building maintenance, and standards compliance; and a third for multiprogram support facilities and small programmatic projects and additions. In FY 1993 more than half of the $\$ 3.3 \mathrm{M} \mathrm{GPP}$ budget will be used for environment, safety, and health-related projects. The remaining funds cannot meet current project needs and do not allow progress in reducing this backlog.
Increasing GPP funding to $\$ 6 \mathrm{M}$ annually and increasing the ceiling from $\$ 1.2 \mathrm{M}$ to $\$ 2.0 \mathrm{M}$ would ensure the success of the Laboratory's safety rehabilitation program and help reduce the current backlog of projects over the next five years.

- General Purpose Equipment (GPE). In the past, essential support equipment has been funded through DOE's Nuclear Physics Division. LBL's Five-Year GPE Plan identifies needs based on DOE prioritization criteria, including those coupled to environment, safety, and health; legal requirements; failed, worn, inefficient, or obsolete equipment; substandard performance; or increased workload and demand. The current funding level of $\$ 1.7$ $M /$ year is inadequate to meet the Laboratory needs. Currently there is a $\$ 38 \mathrm{M}$ equipment backlog for environmental monitoring and fire safety, physical-plant maintenance, mechanical and electrical shops, transportation, and data processing and communications. Increasing GPE support to $\$ 3 \mathrm{M}$ /year would provide a basis for reducing the backlog (see Fig. below).

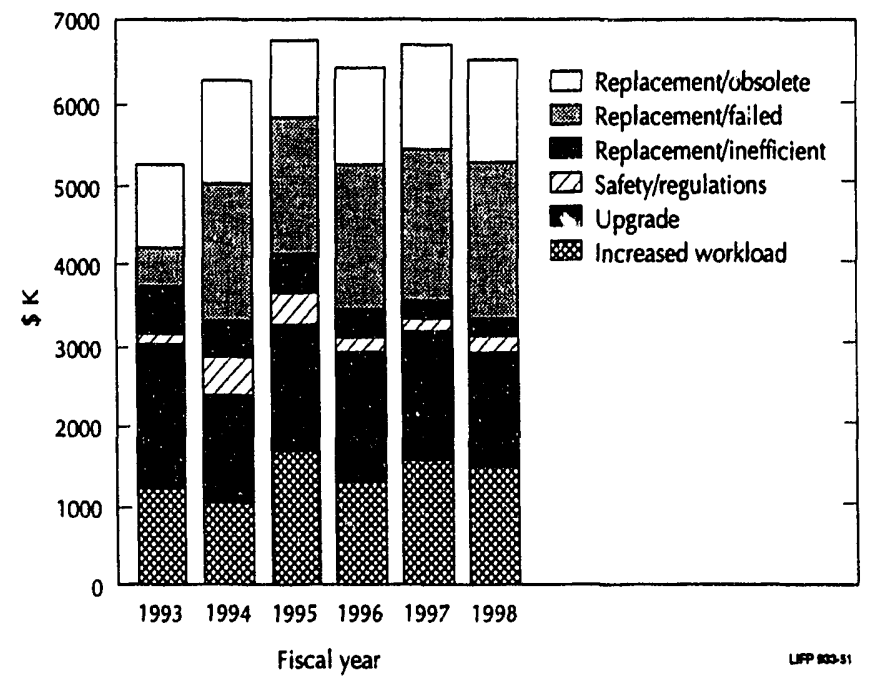

Five-year General Purpose Equipment Needs. 
Appendix: LBL Maps 


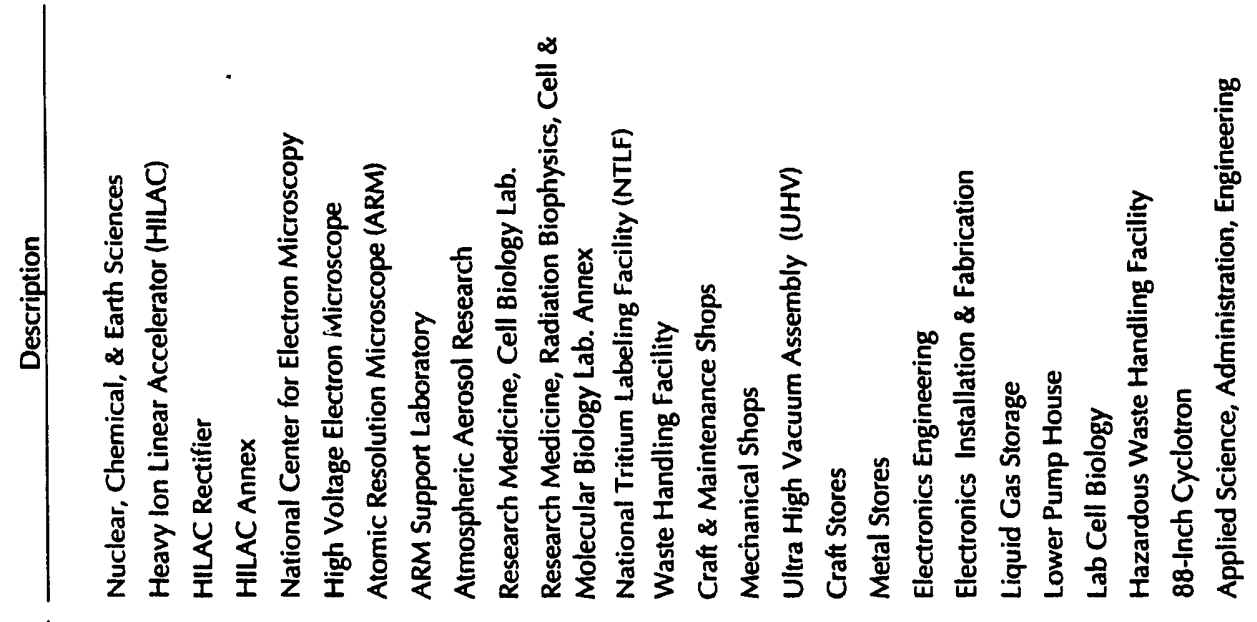

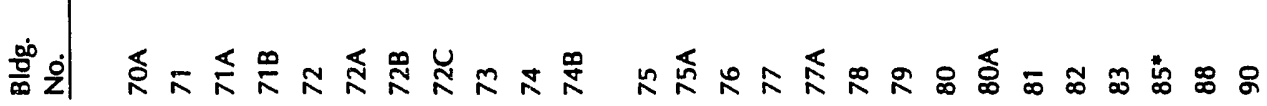

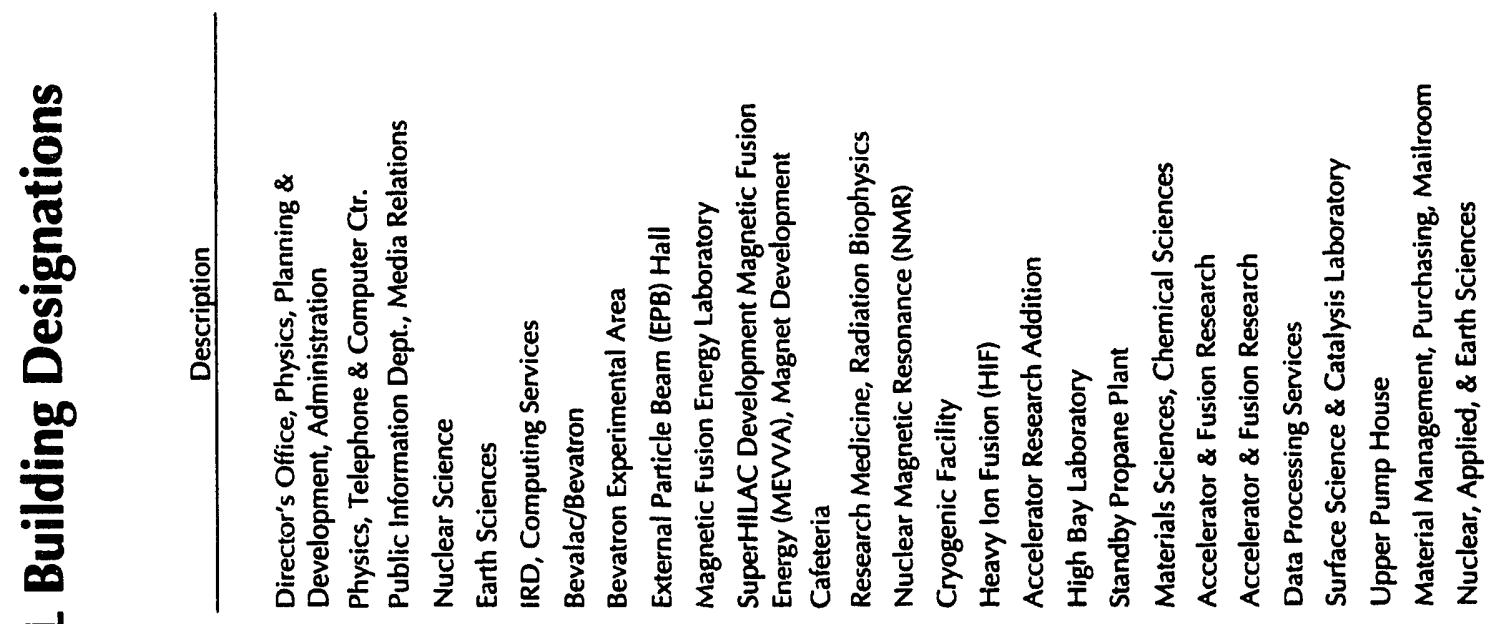

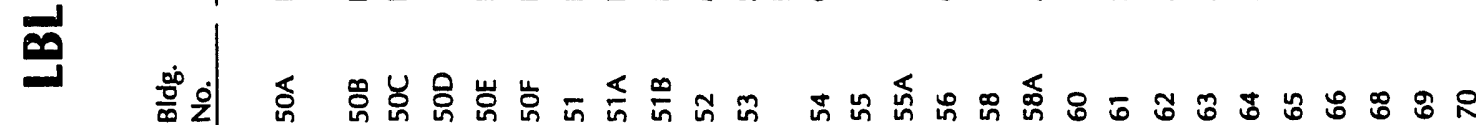

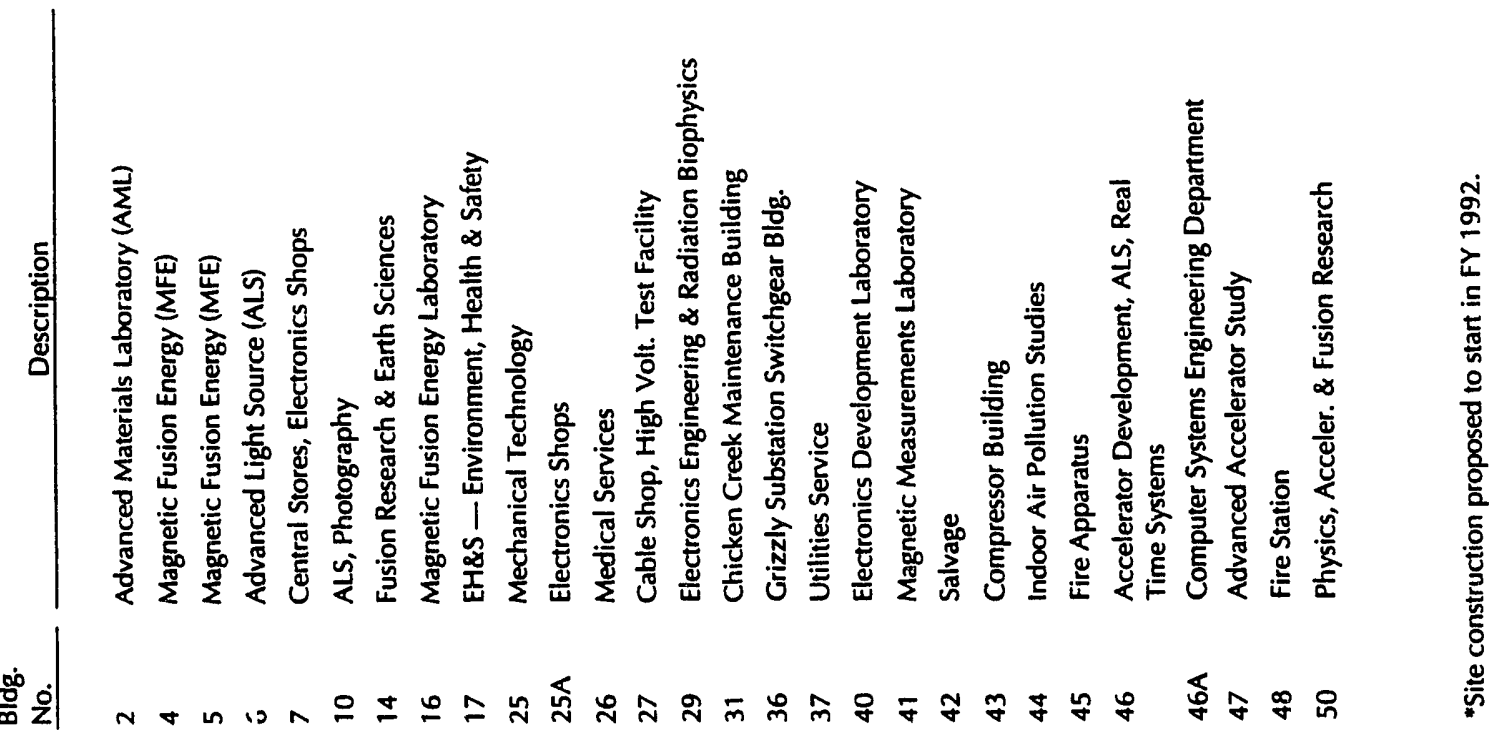




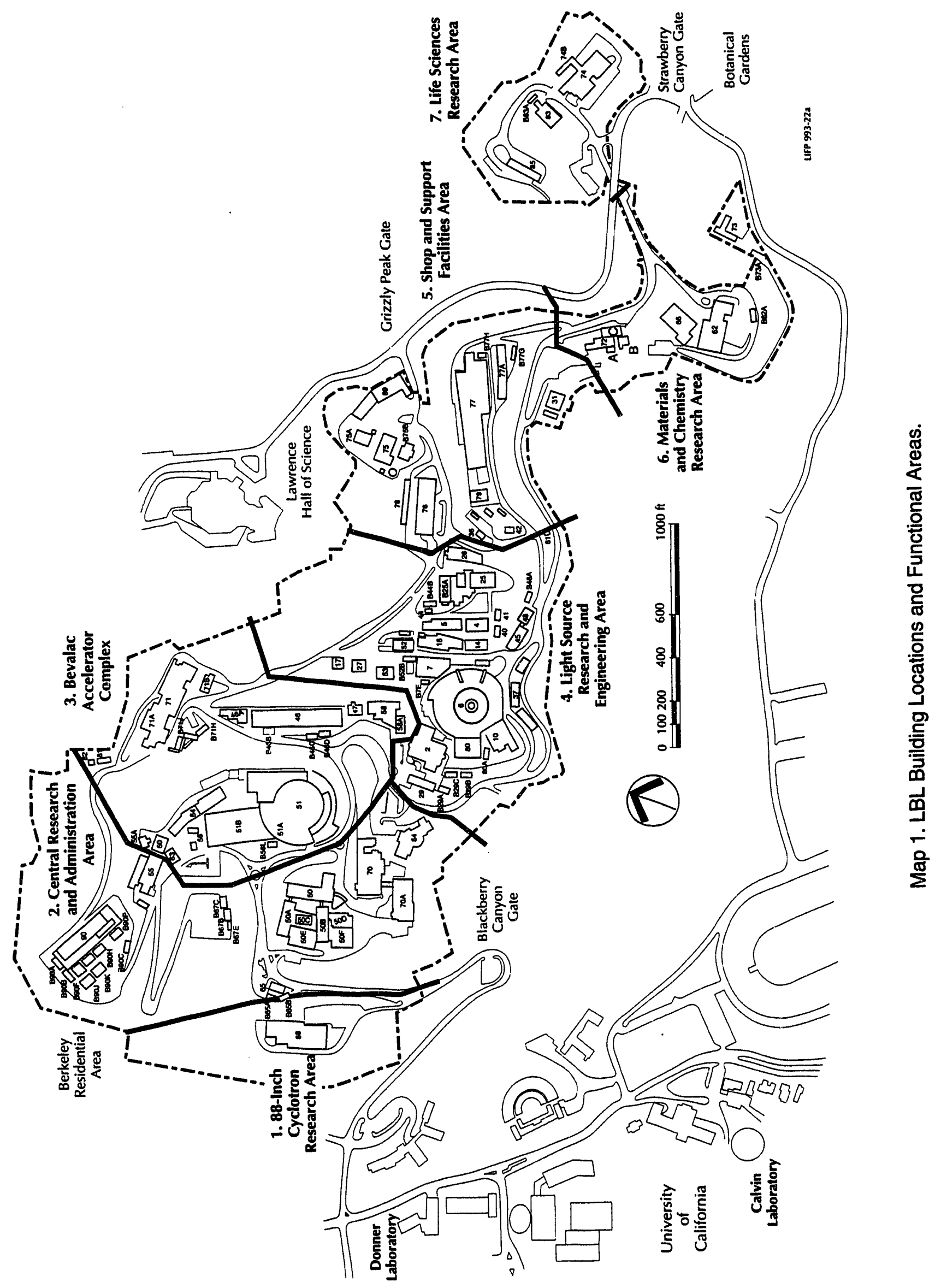




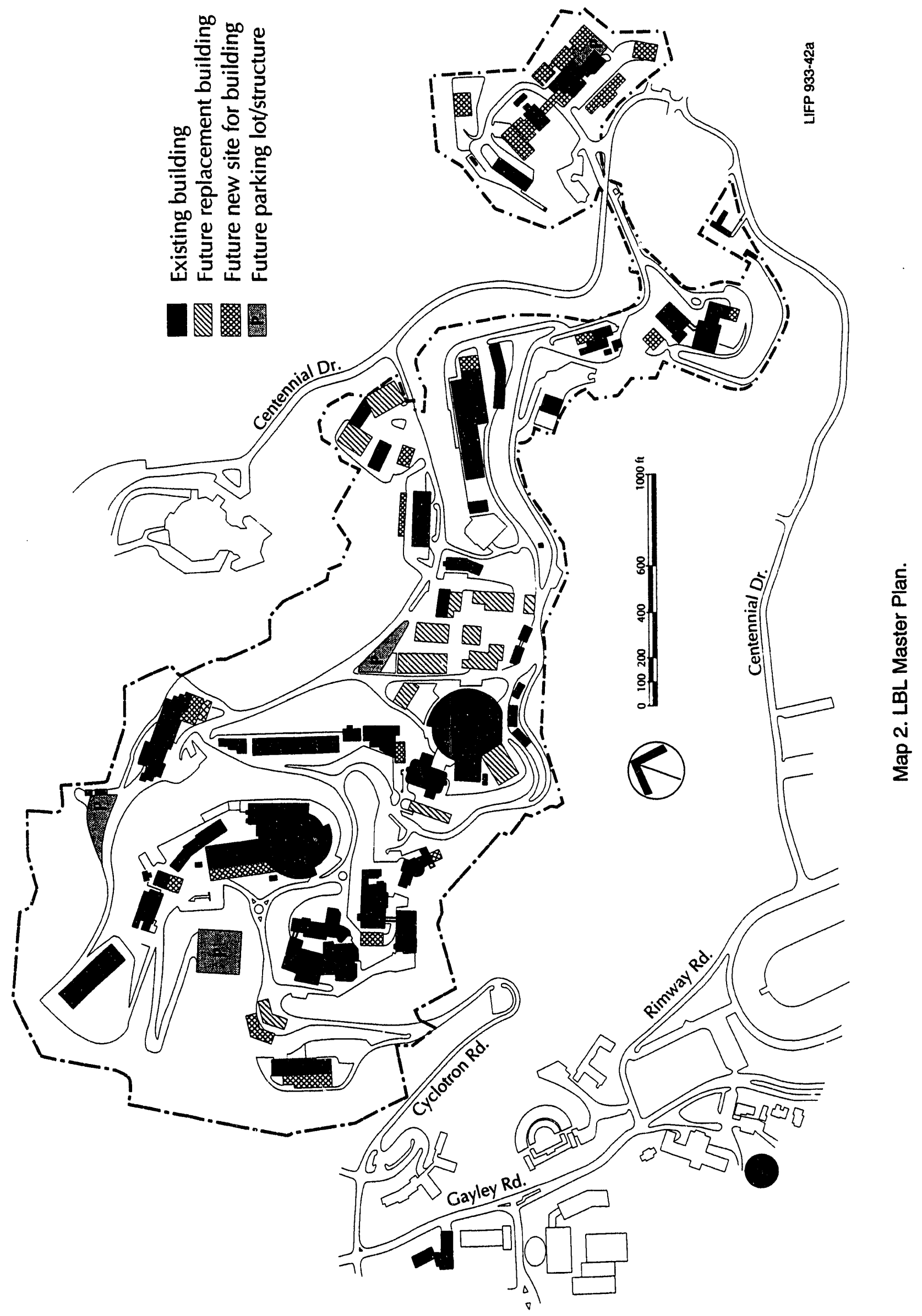




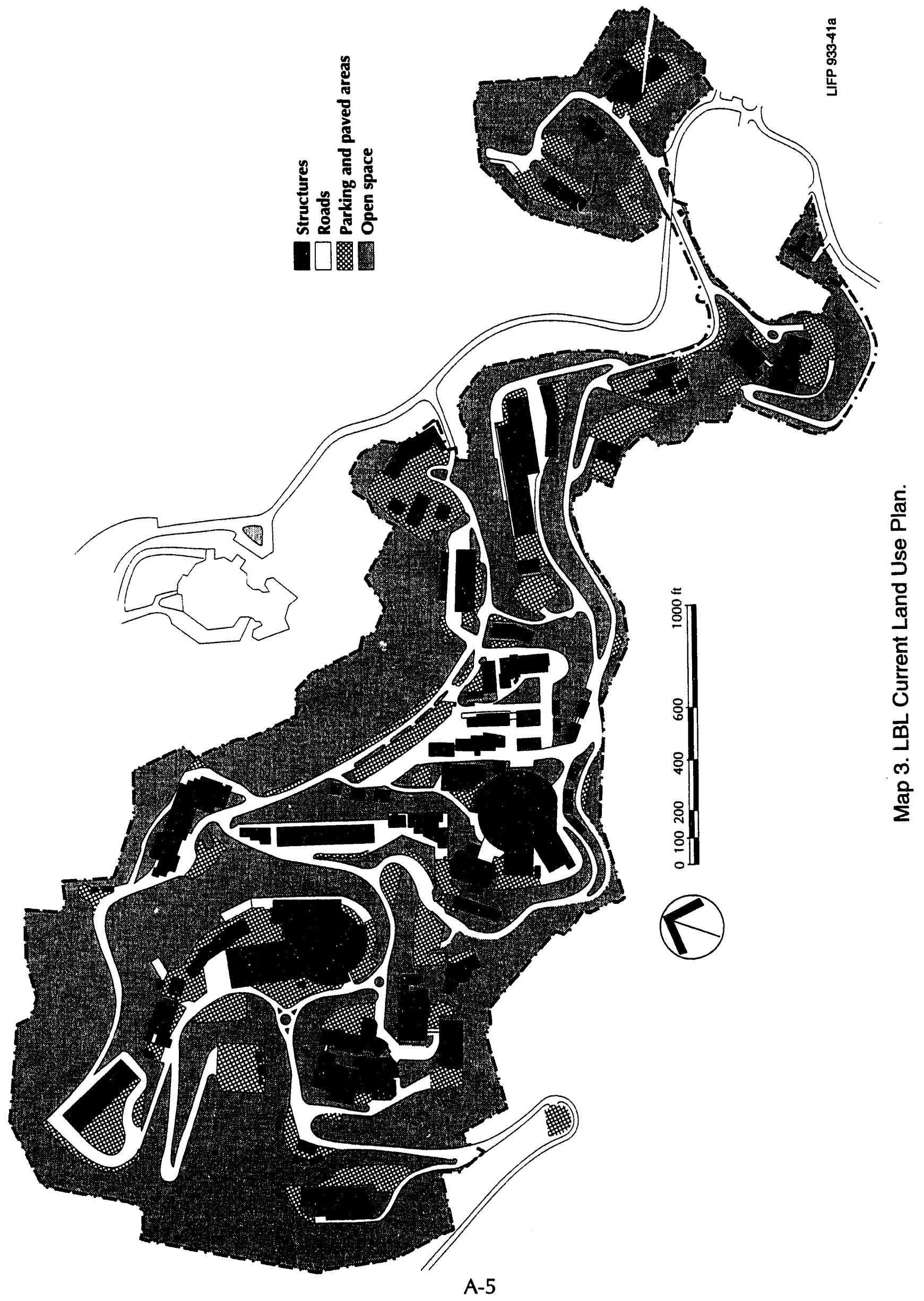




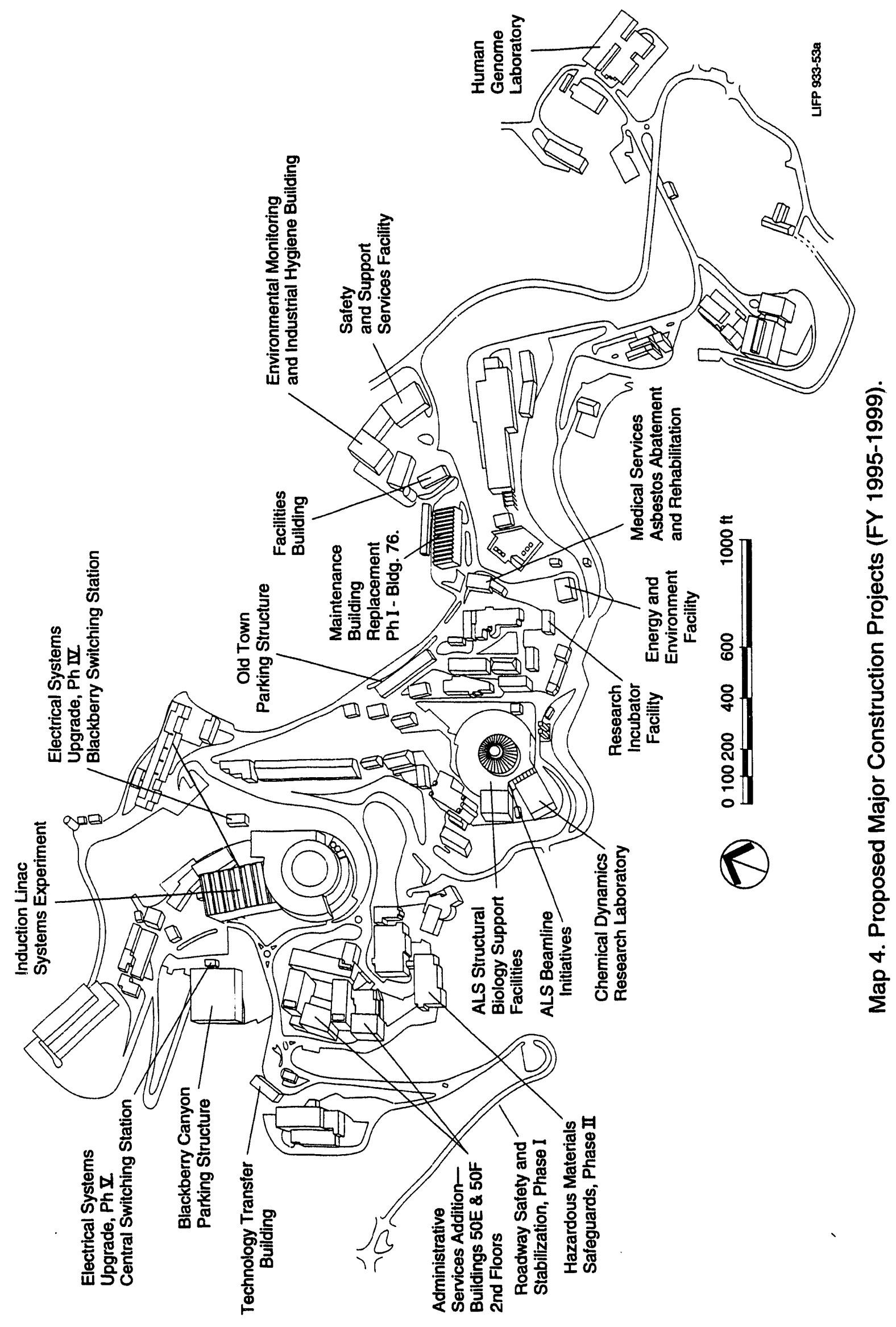



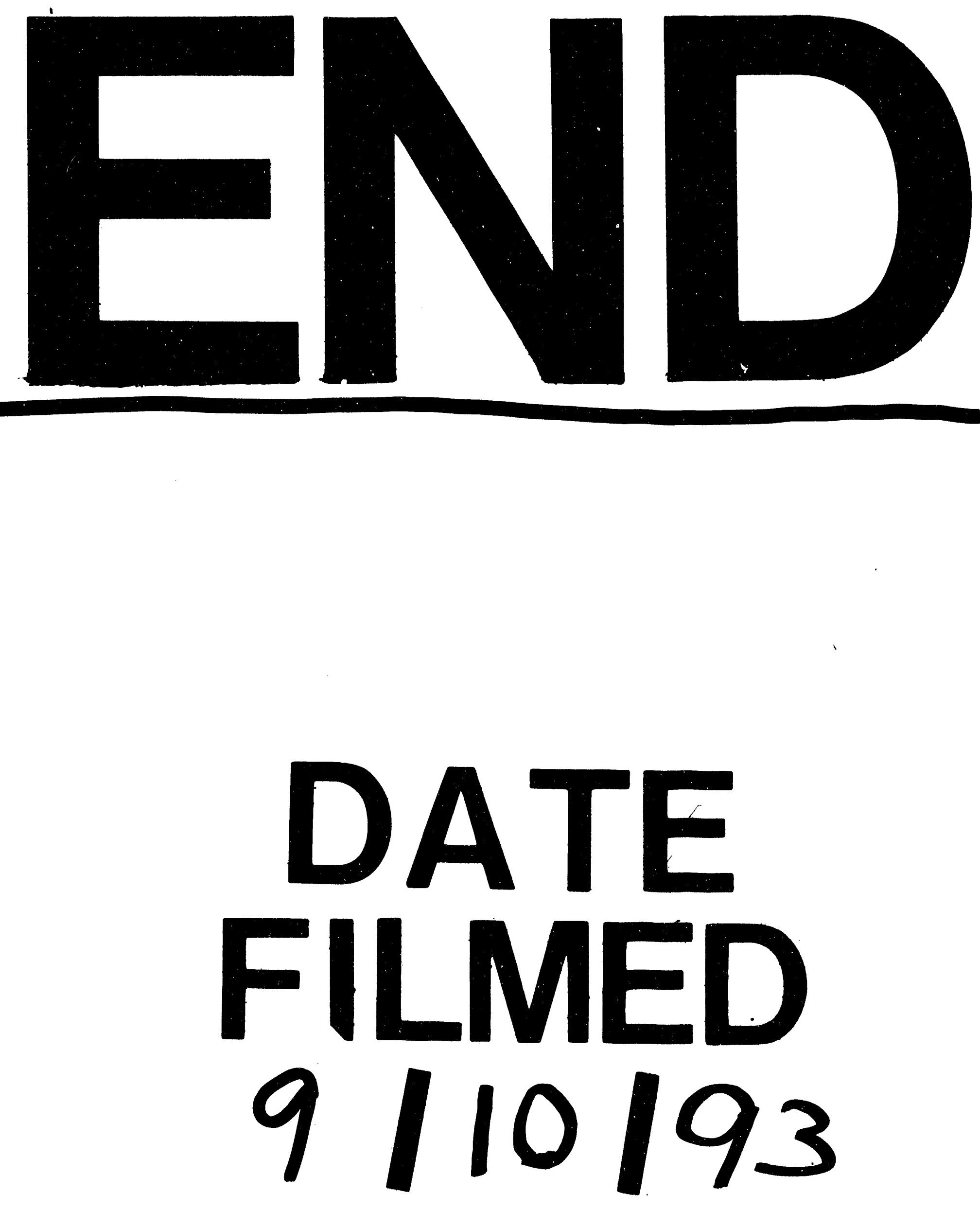
